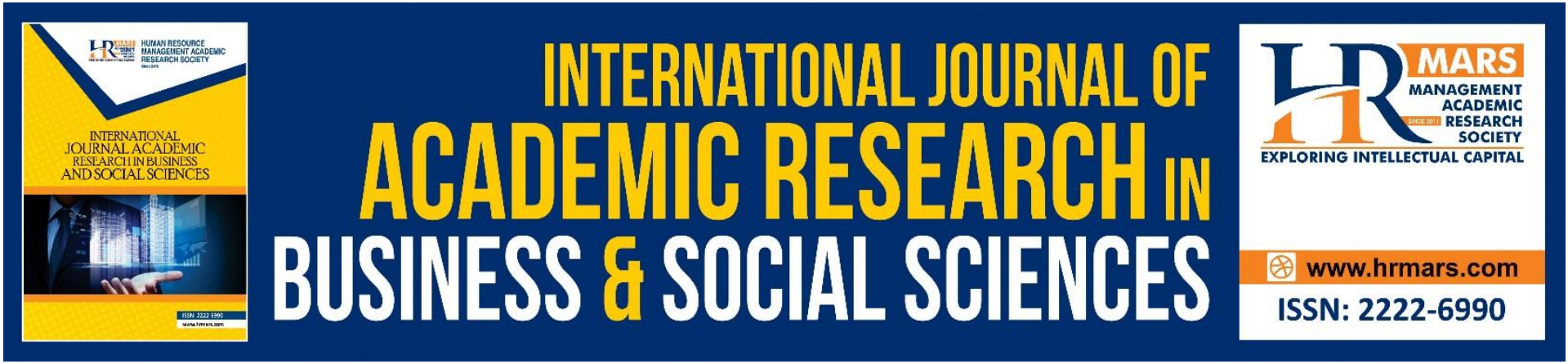

\title{
Myths in Birdman (2014): A Semiotic Study
}

\section{Hamzah Mohamed Tahir, Nur Mahirah Khairul Anuar}

To Link this Article: http://dx.doi.org/10.6007/IJARBSS/v10-i12/8352

DOI:10.6007/IJARBSS/v10-i12/8352

Received: 08 November 2020, Revised: 01 December 2020, Accepted: 16 December 2020

Published Online: 26 December 2020

In-Text Citation: (Tahir \& Anuar, 2020)

To Cite this Article: Tahir, H. M., \& Anuar, N. M. K. (2020). Myths in Birdman (2014): A Semiotic Study. International Journal Academic Research in Business and Social Sciences, 10(12), 527-536.

Copyright: (c) 2020 The Author(s)

Published by Human Resource Management Academic Research Society (www.hrmars.com)

This article is published under the Creative Commons Attribution (CC BY 4.0) license. Anyone may reproduce, distribute, translate and create derivative works of this article (for both commercial and non-commercial purposes), subject to full attribution to the original publication and authors. The full terms of this license may be seen at: http://creativecommons.org/licences/by/4.0/legalcode

Vol. 10, No. 12, 2020, Pg. 527 - 536

Full Terms \& Conditions of access and use can be found at http://hrmars.com/index.php/pages/detail/publication-ethics 


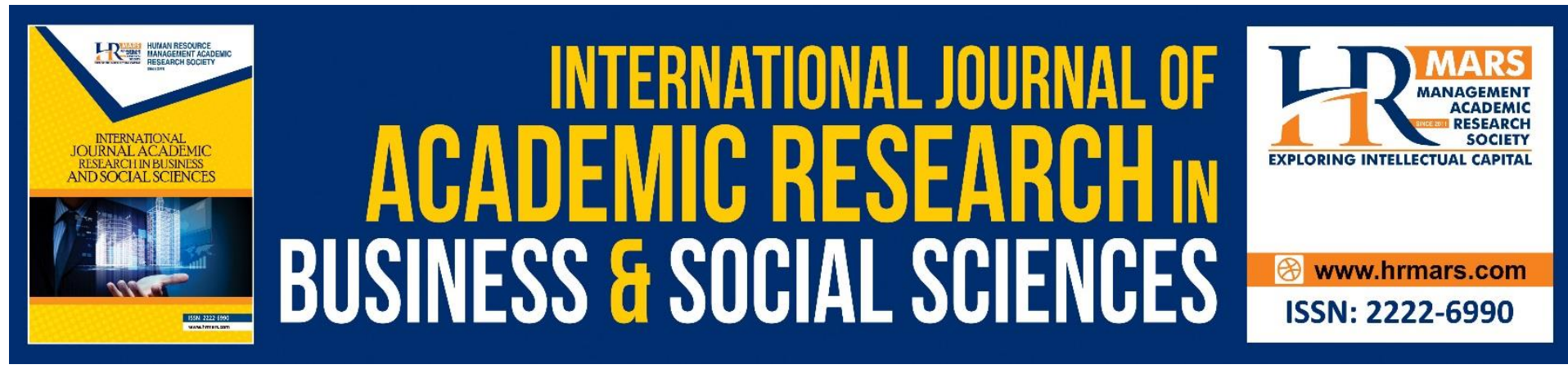

\title{
Myths in Birdman (2014): A Semiotic Study
}

\author{
Hamzah Mohamed Tahir, Nur Mahirah Khairul Anuar \\ Faculty of Film, Theatre and Animation, Universiti Teknologi MARA (UiTM), Selangor Branch, \\ Puncak Perdana Campus, 40150 Shah Alam, Selangor. \\ Email: hamzah390@uitm.edu.my
}

\begin{abstract}
This article will touch on the use of semiotics in Birdman with more emphasis on the myth theory of Roland Barthes. Birdman is a film released in 2014 by Mexican director Alejandro González Iñárritu and the film won four awards at the 2015 Academy Awards, namely Best Motion Picture of the Year, Best Achievement in Directing, Best Writing and Original Screenplay and Best Achievement in Cinematography. As can be seen through this film, it can be said to be an imitation of reality especially in terms of cinematography which uses the long take technique which this technique resembles the view of the human eye. According to its director, he got the idea to produce this film when he was 50 years old. It is at that point that he thinks about how the ego in human beings can change a person's actions in a positive and vice versa. Behind the narrative construction, the director also uses semiotic techniques that make the audience think about the continuity of the Birdman character himself with the main character of the film, Riggan Thomson. Therefore, it is not surprising why this film was able to win the award of Best Motion Picture of the Year and Best Achievement in Cinematography.
\end{abstract}

\section{Introduction}

Semiotics (the science of signs) is a field of knowledge on the use and interpretation of signs. Semiotics comes from the Greek word, sēmeîon which means sign or symbol. Based on the Merriam-Webster (2015) dictionary, the definition of semiotics can be defined as the study of signs and how they are used. Meanwhile, according to the dictionary of Dewan Bahasa 4th Edition (2007), semiotics is the study of signs and symbols, especially the relationship between signs and symbols with the object or idea in question.

According to Chandler (2007) a visual semiotician at Aberystwyth University, semiotics is not only limited to signs alone, but it includes words, sounds, movements, images, and objects. The importance of signs and their meaning has been studied by most historians in the field of philosophy as well as psychology since the time of Hippocrates where he used semiotics in the field of ancient medicine to study the symptoms of the disease (Cobley, 2010). For example, a sore throat is a sign of cough or fever (Sebeok, 2001). 4 In the early 20th century, the study of semiotics began with the intellectual movement of structuralism pioneered by Claude Lévi-Strauss and Swiss linguist Ferdinand de Saussure who was also called the 'father of modern linguistics'. In his book entitled Course in General Linguistic (1916), De Saussure 
uses the term semiology in studying signs. De Saussure divides the semiology into two, namely langue (language) and parole (speech).

This is because he sees the language consists of images and sounds (sound-image) that are closely related to the concept and idea of its use (Syaom Barliana, 2008). Langue according to De Saussure is a system of rules of a conventional nature that governs parole where parole means speech spoken by a person at a particular time. Since De Saussure was also a member of structuralism, he classified the semiotics into two principles, namely signifier and signified. Signifier (image acoustic / sound-image) is something that is physical and can be seen; signified is the meaning of the use of signifier or the meaning or concept behind the object, image, and movement used. The relationship between the two is referred to as signification and it is arbitrary (Sebeok, 2001; Chandler, 2007). For example, the image of a tiger can be seen as a symbol of strength or identity, and it can also be seen as a sign of threat or death. That is what is meant by arbitrary, the meaning behind which can vary based on individual perceptions.

\section{Semiotics Philosophy}

Ferdinand de Saussure's theory of semiotics is largely based on linguistic philosophy. However, there is another influential figure, a pioneer in the field of semiotic studies, Charles Sanders Peirce. Peirce is an American philosopher who studies semiotics (formal doctrine of the sign) and it is closely related to logic (Chandler, 2007). If De Saussure uses semiological terms, Peirce uses semiotic terms that to this day are still used. However, De Saussure and Peirce's concepts and concepts of semiotics are different because each comes from a different philosophical background, but their theories about semiotics are very influential for studies on semiotics today. Peirce is known for his triadic theory (the relationship between three elements or triadic) about semiotics in which semiotics is divided into three namely representamen, object, and interpretant (Peirce, 1955). Peirce's theory should not be interdependent (the relationship between two elements or dyadic), as each of them is very interconnected. Representamen refers to the sign of representation or sign, the object is the concept found in the sign, while the interpreter is the meaning received by a person through the sign (Chandler, 2007). Barthes states that signifiers such as objects, images and styles of behavior cannot be seen if they are not related to linguistics. In other words, linguistics will provide conformation to the meaning to be conveyed (Zinah, 2020).

Peirce in his book entitled Philosophical Writing of Peirce (1955), the representation he meant is a sign or sign which under the sign, there are three other branches namely icons, indexes, and symbols. Although the ideologies and concepts put forward by Ferdinand de Saussure and Charles Sanders Peirce are different, but in theory, they can be seen to have some similarities. Representation by Peirce is the same as the meaning of signifier by De Saussure and the interpreter is signified (Sebeok, 2001). However, both refer to the same thing which is the study of signs (Mudjiono, 2011). In the field of semiotics, there is a branch of study that is very influential to this day which is a myth. Myth is derived from the Greek word, mythos which means tale or speech. Meanwhile, according to 6 Dictionaries of the 4th Edition Language Hall (2007), myth means a story of the past that is considered true that contains elements of concepts and beliefs about the early history of the existence of a nation, country and so on. 
Myth can also be referred to as an ancient fairy tale in which it can be true and also a mere fabrication. In terms of folklore, myth means a folk tale that is passed down through generations through oral (Winzeler, 2008). The word myth is often used in the field of literature. In the field of literature, myth is seen as an eternal human story or image and usually has a relationship with morals or aesthetics and contains magical, magical, and mystical elements. The notion of myth is also closely related to the field of anthropology. Through the field of anthropology, myths are related to human culture or the society that created them. According to Eliade (1960) in the book Myth, Dream and Mysteries, myth is a sacred history that tells of an event that happened in the past. This is supported by a study that examines a myth group of society through visual effects displayed through film; in this study, Myth Barthes theory has been used to see how the reality of a woman's life in her society through the film Hijab. M Rahayu has seen women as weak human beings, has a common myth that only depends on men, women's careers are also based on culture, system, and domestic relations (2020).

However, in the field of semiotics, myth is a communication system that serves to naturalize culture (Zakaria et al., 2013). The study of myth as one of the branches of semiotics was pioneered by Roland Barthes, a French semiotic who studied in-depth De Saussure's theory. Barthes in his book Mythologies (1972) described the myth as a system of communication that gives moral messages. Myth is a form of symbol or discourse to become part of the accepted norms of society (Zogby, 2012). Myths always appear in the form of symbolism that can be symbolized by things which are not always written but can be seen through movies, objects, pictures and so on (Hasanuddin, 1998). Barthes applies semiotics in everyday human life. As a writer, Barthes applied semiotics to the development of human thought and his writings also contained many moral messages which he stated as myths (Iswidayati, 2006). According to Barthes again, myth cannot be defined through the meaning carried by the object but the way the object conveys the message behind it and it is arbitrary. The semiotic theory of De Saussure signifier - signified was further developed by Barthes by adding a sign (Iswidayati, 2006).

De Saussure, who defines semiotics as a scientific study of signs as a part of human social life (Chandler, 2007), seems to have something to do with the mythical concept brought by Roland Barthes. In myth, there are two types of semiotic systems. This is because Barthes evaluates the myth through two perspectives, linguistic and mythical. From a linguistic point of view, signifier in myth is meaning but in myth, signifier is form. Signified, on the other hand, remains the same meaning as the concept. In the field of linguistics, sign is the relationship between signifier and signified. However, in myth, the sign is a whole of the semiotic or semiological system. To illustrate this point, Barthes uses the method of connotation and denotation where denotation means the explicit relationship between sign and reality, while connotation refers more to feelings and emotions. This statement is further strengthened by the writings of Berger (2000) in which he states that denotation is more literal and gives an explicit meaning to a word. Meanwhile, connotations are implicit to the symbolic, historical and emotional associated with it.

\section{Myth of Birdman}

C. Scott Jordan (2019) states that through Birdman, Iñárritu works come from an international perspective tackling issues such as faith and Christianity or the struggles concerning justices 
with a Latino perspective. Birdman is also said to be an informant of a world lost in complexity, riddled with chaos, reflecting on its contradictions. It is common knowledge that Birdman tells the story of its main character, Riggan Thomson, who once played the Birdman superhero character in three previous Birdman movie series. However, Riggan refused to continue the sequel to the film Birdman 4. Instead, he decided to adapt What We Talk About When We Talk About Love, a short story by Raymond Carver to the Broadway stage. Denoted, the aforesaid short story tells the story of a discussion between Nick (Riggan), Mel (Mike), Laura (Laura), and Terri (Lesley) about the meaning of love. Riggan also plays the character of Ed (Terri's husband) who commits suicide when he finds out Terri has a scandal with Mel. However, in connotation, the short story is a real reflection of Riggan's life story. In reality, Riggan divorces his wife, Sylvia because Riggan throws a knife towards Sylvia and a few minutes later Riggan says that he loves Sylvia. Meanwhile, in the staging, Ed finds that Terri has a relationship with Mel and Ed acts to kill Terri.

Going back to Riggan's action to stage What We Talk About When We Talk About Love, this is because Riggan wants his name to be known for his talent, not because of his acting Birdman character. The staging is a testament to Riggan that he is a versatile actor, still relevant and well-known. Like the dialogue of a journalist who interviewed Riggan in the 00:10:32 minute, "Are you afraid at all that people will say you're doing this play to battle the impression that you're a washed-up superhero?", While Riggan replied, "No. I "m not. And that "s exactly why 20 years ago I refused to do Birdman 4."

Thus, after the semiotic theories of some scholars are studied and researched, this writing will apply the semiotic theory of Roland Barthes's model on connotations, denotations, and even myths, without excluding the semiotic principles of the visual nature.

The dialogue in both visuals was uttered twice by Riggan during the staging of the short work. The first visual depicts Riggan as Nick. Meanwhile, the second visual depicts Riggan as Ed. The writing of this thesis found that the two dialogues were "pressed" by the director because they were a sign (connotation) to Riggan's true character without the audience realizing that he was a narcissist. This statement can be supported by the discovery of an article on Riggan's narcissistic character composed by Alex Brannan. According to Brannan (2016), the scene in the first visual is an initial indication of Riggan's narcissistic character and this will be explained further in the next paragraph.

According to Webber (2016), narcissism is a feeling of "self-mirroring" driven by the ego within oneself, and individuals with this narcissistic character are very selfish, lack empathy for others, and crave admiration from the people around them. Webber also states that narcissistic behavior can lead to depression because individuals like this have a constant need to feel their power is recognized by the people around them and when reality shows otherwise, the effect on them can lead to depression. Besides, the problem of depression can also invite the problem of delusions and hallucinations that Riggan also experienced and it will be discussed in the second small topic later.

In addition, they are also grandiose and they like to see their faces in the mirror because they are very obsessed with the ideal image of themselves (Ashmun, 2008). If observed, Riggan's room is the main location because in the room there is a mirror and after analysis, there are 
three scenes of Riggan looking at himself in the mirror because the mirror is a subtle message to state that Riggan is a narcissist. Besides, Riggan also has the nature of egomania or selfishness which means a feeling of obsession with oneself whether in terms of beauty, abilities, ingenuity, and so on. It is found to stem from a selfish narcissistic character (Griffiths, 2015). Griffiths added that egomania is often experienced by celebrities and politicians because such people need attention from the world and they really need admiration from their fans and because of that their ego is very high and they always want love and admiration from the people around them and things this is what Riggan experienced as a result of his narcissistic character. Such people are driven by a high level of ego in themselves to achieve what they want. Most selfish individuals also experience the problem of delusions of their greatness and that is what deceives their views on their shortcomings and abilities and this will be discussed further in the next small topic.

Going back to his first visuals and dialogue, denoted, the scene portrays Riggan as Nick, standing in the middle of the stage close to the audience (to steal the audience's attention), and the spotlight shines toward him. Riggan tells the story of how an old man suffered from depression because he could not see his wife's face just because he could not turn his face away. However, in its connotation, based on Riggan's position that requires the audience to only look at himself on the stage is a reflection of Riggan's career journey that he craves to be recognized. The narcissist individual likes the attention of the public and as well as the second visual, Riggan who plays the character, Ed, when he finds out Terri is no longer in love with him, he stands in the middle of the stage facing the audience and shoots himself. That's why Riggan takes the scenes that can highlight his greatness as a washed-up superhero because he needs the attention and focus of the people on him because he wants a feeling of admiration (admiration) from the audience.

In addition, individuals with narcissistic traits also cannot accept criticism and can act aggressively if criticized (Seltzer, 2013). To prove that Riggan is indeed a narcissist, there is a scene from the minutes 00:54:14 to the minutes 00:58:30 to prove this statement. Denoted, Laura enters Riggan's room carrying a newspaper featuring Mike Shiner's article as the frontpage headline. When Riggan opens to page 12 , the article for himself seems to downplay his talent with a cynical sentence structure and little content. Riggan feels challenged because Mike has stolen the front page of a newspaper that should be his own because he is the one who worked hard for the staging What We Talk About When We Talk About Love. Then, Riggan confronted Mike and punched him. Riggan's narcissistic character can prove the statement from Seltzer above. Riggan could not accept the criticism and to allay his "scratched ego", he vented his anger by punching Mike. When he returned to the room, the anger inside him had not disappeared and Riggan acted out of control by smashing things around him using his "telekinetic" power.

If you scan the minutes before the story begins, there is a montage of Late Fragment poems by Raymond Carver. According to the montage, Raymond Carver already has what he wants in his life, which is to call himself the beloved and feel himself to be the beloved of the earth. Then, the next montage shows the word Birdman in gray and the word amour (meaning love in Latin) in red. 
In connotation, this montage is a sign of Riggan's desire in his life. Throughout his life, he wanted to feel like a loved one on earth. Additionally, Riggan's main purpose of staging What We Talk About When We Talk About Love is because of the note from Raymond Carver that he received during his school days, and through that note, he feels indeed the destiny of his life to be the greatest. At the beginning of the story as well (minute 00:02:53), Riggan asks Sam to buy Alchemillas flowers or any other flowers other than roses because Riggan wants flowers that can calm him down. When Riggan finds out that Sam bought him a rose, Riggan uses his 'telekinetic' power by destroying the rose vase (minute 00:08:58). Why did Riggan destroy the rose vase? This can be evidenced by the scene in the 01:35:25 minute, in which Riggan does not like roses.

Furthermore, through some of these scenes, we can see how Riggan feels that he is quite "loved" by the people around him because symbolically, roses carry the meaning of love or affection. The Alchemillas or Lady "s Mantle flower requested by Riggan at the beginning of the story acts as internal healing because the flower can soothe the soul. However, the flower has a myth behind it. According to Picton (2000) based on folklore, dew from Alchemillas flowers can convert metal to gold. This can be adapted to the condition of Riggan who wants something ordinary to turn out to be extraordinary. For example, with the staging of What We Talk About When We Talk About Love in which Riggan as a director, adaptation writer, and even actor, can re-emerge his name that has been 'lupus' in the industry. This can be proven through some visuals that show Riggan's "position" now in the industry.

Based on the first visual, as soon as Mike says no one cares about Riggan in New York City, suddenly a woman criticizes Riggan's whereabouts and asks permission to take a picture. Cynically, the woman asked Mike to take a picture of them. However, the girl's son did not know Riggan. In connotation, through this scene, children and teenagers living in the background of the Birdman movie, do not know who Riggan Thomson is. Although mythically, children and teenagers certainly have one of their favorite superhero characters, yet they do not know a superhero named Birdman. Only those who are as old as the female character know who the actor behind the bird suit is. This clearly shows that only a handful of people still know Riggan.

Meanwhile, the second visual shows the expression of Sam's heart towards Riggan, towards his ambition to re-proclaim his name as before. According to Sam, Riggan only staged What We Talk About When We Talk About Love because Riggan wanted his name relevant in the growing entertainment industry. Mythically, to maintain a name as an entertainer or an actor is not easy. Every day, there will always be many new artists who will gradually 'erase' the names of old artists in the industry. Just like Riggan, when he refused to continue the Birdman 4 franchise, his name plummeted because the audience only knew the Birdman character but not the actors in the suit and that is why Riggan tried to stage What We Talk About When We Talk About Love to "preserve" his name again. Like the montage of the Late Fragment poem by Raymond Carver, with the narcissistic character of Riggan, he expects himself to be admired by all and then confuses him with the meaning of love and admiration.

\section{Conclusion}

If we look at Birdman from the eyes of an audience that does not know the field of film, they would think it is about a superhero character who has magical powers, just like the other 
renowned superhero characters. However, when we look at this film through the eyes of an individual who knows the field of film, they will see Birdman from the connotation point, that is, the meaning behind the visuals displayed, which this knowledge guides the audience to explore the film in more depth.

The film, which uses long take cinematography techniques, also won the Best Achievement in Cinematography award, as the film plays with the audience's consciousness because the imaginary line between the real world and dreams is very fragile and difficult to distinguish. For example, when we see Riggan swinging things around him using his telekinetic power, we must assume the matter is real and Riggan does have telekinetic power but then the assumption becomes fragile when another character interrupts and sees for himself how Riggan smashed the goods -items around him using his hands.

Like Birdman and the character of Riggan Thomson, every human being has an ego within themselves and it is this ego that drives human beings in a positive or negative direction. According to the author, if viewed from denotation as a whole, Birdman is a representation of the character of man himself who wants other human beings to know them as a great individual and this is what is said to be lust because, as human beings, we are kings to ourselves and we are also the ones who control all our behavior based on different passions and each one affects our daily behavior. When a person is at the lowest level of lust which is an-Nafs al-Ammara, they are easily influenced by the devil so that they ignore the people around them and act out of control (Ahmed, 2007; Mughal, 2019). According to Shaykh Zulfiqar Ahmed also, narcissistic individuals are among the examples of individuals who are at the level of an-Nafs al-Ammara and this statement can be attributed to the character of Riggan who is a narcissist.

In the Qur'an there is a statement about the lust of anger. Through surah Yusuf, verse 53, Allah SWT states how the lust of anger is very powerful in influencing human beings in doing evil things. To overcome the lust of anger, the human being must always recite dhikr remembering Allah SWT so that the lust of anger can be completely controlled. In the context of Birdman, as can be seen through Riggan's character, every time Birdman's soft voice appears and tries to influence him, and that's when Riggan practices the verses from the practice of mindfulness to calm his anger so that he is always calm and conscious so that he is not directly influenced by his inner "voice". Since the main focus of this writing is on the analysis of myths found in Birdman, it can be proved that this film indeed applies myths in its narrative without the audience realizing it. Among the myths that have been identified are the myth of Narcissus, the myth of Icarus, the phoenix and some other myths. According to the author, the main purpose of its director who is also a scriptwriter, Alejandro González Iñárritu to apply myths in Birdman narrative is because each myth has its lessons. Like the myth of Narcissus, the feeling of obsession with the ideal reflection of oneself in the water makes Narcissus look at his beauty to death. Meanwhile, the myth of Icarus, ambitious or ambitious nature makes Icarus forget about his lack of self so that it makes his wings burn and eventually he falls into the sea.

Characters like Narcissus and Icarus found in these myths are a reflection of the nature of ego or human lust that always wants more. That is why, ego or lust is very powerful in influencing our daily actions and as human beings, we must wisely control our ego or lust because high 
ego can plunge us in a negative direction. Through film, we can apply that imagination into a visual form that can be seen and appreciated by the public. From an imagination, we combine it to produce a story that we then describe in visual form. That is why the film is an art form because we express in the storytelling space of the film. That is what every director is trying to convey behind his films. Every film that is produced must have a story behind it and as a viewer who is conscious or aware of what he is trying to convey, he will be able to receive the message. Such is the result of this scientific study that focuses on the myths found in Birdman analyzed using the semiotic theory of Roland Barthes model.

\section{References}

Ashmun, J. M. (2008). Narcissistic personality disorder [Web log post]. Dipetik daripada http://www.halcyon.com/jmashmun/npd/traits.html

Barthes, R. (1972). Mythologies. New York, NY: The Noonday Press. analysis of film. Bloomington, IN: Indiana University Press. Berelson, B. \& Steiner, G. A. (1964). Human behavior: An inventory of scientific findings. New York, NY: Harcourt, Brace \& World. isepi:Berger, A. A. (2000). Media and communication research methods. Thousand Oaks,

Cobley, P. (2010). The routledge companion to semiotics. Oxon, Oxford: Routledge. Definition of semiotic by Merriam-Webster. (2015). Dipetik daripada http://www.merriamwebster.com/dictionary/semioticisepiDermentzopoulos, C. \& Vassiliou, T. (2014). Approaching an abstract cinematic form: The Tree of Life by Terrence Malick. Journal of Literature and Art Studies, 9(4), 722-728. Dipetik daripada http://www.davidpublishing.com/davidpublishing/Upfile.pdf

Griffiths, M. (2015). The ego has landed: A personal look at egomania [Web log post]. Dipetik daripada https://drmarkgriffiths.wordpress.com/2013/03/06/the-ego-has-landed-a personal-look-at-egomania/sẸp.Hajah Noresah bt. Baharom. (2007). Kamus dewan bahasa dan pustaka (Edisi ke-4).

Jordan, C. S. (2019). POSTNORMAL AMERICA AT THE MOVIES. In SARDAR Z. (Ed.), The Postnormal Times Reader (pp. 229-241). International Institute of Islamic Thought. doi:10.2307/j.ctv10kmcqv.15

Kuala Lumpur: Dewan Bahasa dan Pustaka. terhadap film In The Name of God. (Tesis Sarjana. Universitas Negeri Syarif Hidayatullah, Jakarta, Indonesia). Dipetik daripada http://repository.uinjkt.ac.id/dspace/handle/123456789/21832 Hasanuddin. (1998). Pengaruh mitos dalam karya sastra Indonesia Warna Lokal Minangkabau.

Rahayu, M. (2020). Mythology Of Career Woman In Hijab Film (Study Of Roland Barthes Semiotic Analysis) American Journal of Humanities and Social Science Research, Volume-4, Issue-7, pp-80-86

Peirce, C. S. (2011). Philosophical writings of Peirce. Mineola: Dover Publications. Pick, Z. M. (1981). Cinema as sign and language. Canadian Journal of Political and Social Theory, 5, 199-207. Dipetik daripada https://journals.uvic.ca/index.php/ctheory/article/view/13905:Sépipicton, M. (2000). The book of magical herbs: Herbal history, mystery \& folklore.

Ahmed, S. Z. (2007, September 16). Struggling against one's base desires (Nafs) [Web log post]. Dipetik daripada http://www.tasawwuf.org/writings/sermons/struggle_nafs.html

Iswidayati, S. (2006). Roland Barthes dan mithologi. Imajinasi: Jurnal Seni, 2 (2), 42-54. 
Sujato, B. (2012). A history of mindfulness. Taipei: The Corporate Body of the Buddha Education Foundation.

Webber, R. (2016, September 5). The real narcissists [Web log post]. Dipetik daripada https://www.psychologytoday.com/articles/201609/the-real narcissists

Mudjiono, Y. (2011). Kajian semiotika dalam film. Jurnal Ilmu Komunikasi, 1(1), 15-33.

Mughal, H. A. (2019). Support at Work and its Relationship with Employee Performance:

Critical Insights for Early Scholars. Annals of Contemporary Developments in Management \& HR (ACDMHR), 1(3), 16-21.

Zinah, A. (2020) Birth and Growth of Semiotics. International Journal of Research in Social Sciences and Humanities, Vol 10 (IV.Oct-Dec)

Zogby, J. (2012). An examination of psychoanalytic and semiotic film theory using Metropolis, Blade Runner and The Matrix. (Tesis Master). Boleh didapati daripada ProQuest Dissertations \& Theses Global. (1009735476). Dipetik daripada http://search.proquest.com.ezaccess.library.uitm.edu.my/docview/100973547 ?accountid $=42518$ 